\title{
FLAMMABILITY OF ORNAMENTAL SPECIES FOR FIRE MANAGEMENT IN WILDLAND-URBAN INTERFACE IN PARANÁ STATE
}

\author{
Antonio Carlos Batista ${ }^{1 *}$, Daniela Biondi ${ }^{2}$, Angeline Martini $^{3}$ \\ 1* Universidade Federal do Paraná, Departamento de Ciências Florestais, Curitiba, Paraná, Brasil - batistaufpr@ ufpr.br \\ 2 Universidade Federal do Paraná, Departamento de Ciências Florestais, Curitiba, Paraná, Brasil - dbiondi@ufpr.br \\ 3 Universidade Federal de Viçosa, Departamento de Engenharia Florestal, Viçosa, Minas Gerais, Brasil - martini@ufv.br
}

Received for publication: 10/07/2019 - Accepted for publication: 16/06/2020

\begin{abstract}
Resumo
Inflamabilidade de espécies ornamentais para o manejo do fogo na interface urbano-rural do Paraná. O objetivo deste trabalho foi avaliar a inflamabilidade de espécies ornamentais para o manejo do fogo em áreas da interface urbano-rural do Paraná. Para isso foram selecionadas espécies ornamentais nativas e exóticas. Preliminarmente foram avaliadas as seguintes características morfológicas das folhas associadas à inflamabilidade das espécies selecionadas: textura, exsudatos, pilosidade e enervação. Em seguida procedeu-se à análise das características de inflamabilidade das espécies em experimentos de queima. Foram realizadas 50 queimas de $1 \mathrm{~g}$ de material vegetal recém-colhido de cada espécie em um epirradiador, sendo que as variáveis coletadas foram: frequência de ignição (FI), tempo para ignição (TI), duração da combustão (DC) e índice de combustão (IC). Estas variáveis foram analisadas estatisticamente pelo teste SNK a 95\% de probabilidade. Também foi realizado o teste de conglomerado Cluster para identificar distintos níveis de inflamabilidade das espécies testadas em função das características morfológicas e dos parâmetros de inflamabilidade obtidos nos ensaios de queima no epirradiador. Os resultados demonstraram que FI e TI foram menores na maioria das espécies nativas (exceto Verbena rigida), diferenciando-se estatisticamente das exóticas. Houve diferença entre as espécies em função das características morfológicas das folhas e os parâmetros de inflamabilidade medidos durante as queimas. Pode-se inferir que a maioria das espécies nativas foram consideradas pouco inflamáveis e as exóticas inflamáveis, com exceção da espécie Euonymus japonica, classificada como de inflamabilidade nula. Conclui-se que as espécies nativas são mais indicadas para o uso em manejo do fogo em áreas de interface urbana-rural no Paraná, devendo ter seu uso intensificado no paisagismo.

Palavras-chave: Interface urbano-rural (WUI), Espécies nativas, Epirradiador.
\end{abstract}

Abstract
The objective of this work was to evaluate the flammability of ornamental species as a tool for fire management in areas of wildland-urban interface in Paraná. For this, native ornamental species and exotic species were selected. Initially, the following morphological characteristics of the leaves, which are associated with the flammability of the selected species were evaluated: texture, exudates, hairiness and enervation. The flammability characteristics of the species were analyzed through burning experiments. Fifty $1 \mathrm{~g}$ burns of freshly harvested plant material of each species were conducted in an epiradiator. The variables collected were: ignition frequency (FI), time to ignition (TI), combustion duration (DC) and combustion index (CI). These variables were statistically analyzed by the SNK test at $95 \%$ probability. The Cluster test was also performed to identify different levels of flammability of the species tested as a function of the morphological characteristics and the flammability parameters obtained in the epiradiator tests. The results showed that FI and TI were lower in most native species (except Verbena rigida), differing statistically from exotic ones. There were differences among the species as a function of the species leaf morphology and the flammability parameters measured during the burning. It can be inferred that most native species may have been considered slightly flammable and exotic as flammable, with the exception of the species Euonymus japonica, classified as zero flammability, concluding that native species are the most suitable for use in fire management in wildland-urban interface areas in Paraná, and should be intensively used in landscaping.

Keywords: Wildland urban interface (WUI), Native species, Epiradiator.

\section{INTRODUCTION}

The behavior of forest fires and the mechanisms involved in this process are highly complex. Due to the interrelations between fire and ecosystems, the current trend is to address the problem of forest fires in a more holistic view, which has generated the term "fire management", much broader than simply prevention and control of forest fires. Fire management refers to the set of technical decisions and actions available to prevent, preserve, control or use fire according to the characteristics and needs of each ecosystem.

The classification of forest fuels according to their flammability is an essential component for fire risk assessment in the context of forest fire management planning. Researchers and managers have long identified the

FLORESTA, Curitiba, PR, v. 51, n. 1, p. 192-200, jan/mar 2021.

Batista, A. C. et.al.

ISSN eletrônico 1982-4688

DOI: $10.5380 /$ rf.v51 i1. 67938 
need to classify the flammability of forest species to use in fire prevention and fire prevention plans and to improve predictive models of fire behavior. It happens because the vegetation properties can contribute to a greater or lesser speed of fire propagation and the type of fuel is the main propagation enhancer or retarder, since the other variables are practically uncontrollable (SOUZA; VALE, 2019).

From the point of view of natural resources management, the interaction between natural and urban areas is called the wildland-urban interface (WUI), which can be translated as "urban-rural interface", which are places with mixed characteristics, being influenced by both, rural and urban areas (BIONDI, 2013). According to the same author, with the increase of the urban population at national and world level, the interface areas are losing this transition characteristic of rural or urban physiognomy. One of the most common problems due to this urban / rural proximity is the forest fires that cause a lot of damage to homes in urban areas. Fire sources are mainly due to the proximity of areas with agricultural and forestry monocultures that use fire in their cultural crop management (BIONDI, 2013).

A protective strategy is the replacement of susceptible vegetation by species that can inhibit the spread of fire, thus, plants of low flammability are used as another tool for the management of forest fires, with such species being included in firebreaks (SOUZA; VALE, 2019). Establishing firebreak areas to prevent or reduce the spread of fire from one area to another is a very simple and effective preventative forestry technique (BATISTA et al., 2013). Forest fire prevention techniques and measures taken in the urban landscape around the homes provide access to personnel, combat equipment, and reduce fire hazards and damage.

In European countries, homeowners in WUIs are often advised to eliminate the use of highly flammable vegetation when landscaping their homes and lists containing species that are appropriate for use in firewise landscaping are often requested (GANTEAUME et al., 2013). However, in Brazil there has been non-concern with these factors for the choice of species in WUI areas and when there is so, the base is focused mainly on empiricism. So, one of the major difficulties in implementing green barriers is to identify suitable species for formation of these structures (BATISTA et al., 2013).

Reducing the fire hazard can be accomplished by appropriate arrangement, maintenance and selection of species for landscaping homes (GANTEAUME et al., 2013). Therefore, the knowledge of how species differ in their flammability characteristics is necessary to elaborate lists of recommended plants and trees for urban and residential usage in wildland-urban interface areas (WHITE; ZIPPERER, 2010). On the one hand, there is this growing demand for the preparation of lists of species recommended for implantation in WUI areas, while on the other hand, there is a great scarcity of scientific data on the vegetation flammability.

Modeling has become an essential tool in research on forest fires and is currently a crucial tool for studies on risk mapping, fire propagation, and forest management (MOLINA et al., 2017). Experimental studies are needed both to calibrate and to validate prediction models. Ignition, fire behavior, risk assessment, and fire control require a thorough understanding of the chemical and physical processes involved in forest fires. As forest fuels burn and what parameters have the greatest influence on the combustion process are issues that need to be addressed (BARTOLI et al., 2011).

Forest fires affect vegetation which, in turn, affects the behavior of fires, since the plant species that supply the fuel for the fires have specific flammabilities (CURT et al., 2011).

Climate change over the last decades has been cited in countless reports and surveys as one of the main causes of the increase in the frequency and magnitude of forest fires. Several climatological and ecophysiological models design drier, hotter conditions and therefore a higher risk of forest fires (MORENO, 2009). However, the frequency and magnitude of the fires depend not only on the meteorological conditions, but also on the characteristics of the vegetation, especially its flammability (DELLA ROCCA et al., 2017).

Flammability can be considered as the easiness with which the material ignites and can also be understood as the resistance of the plant species in initiating and propagating fires. Furthermore, it can be defined as the ease of the material to catch fire, both spontaneously and when exposed to certain conditions (ZHAN et al., 2011).

The flammability of the vegetation is usually associated with the hydration of the plants, although there are other factors that affect this characteristic. Some species are more flammable than others, even though they present the same moisture content. In addition to leaf moisture, volatile organic compounds, such as monoterpenes, is another possible factor contributing to the increase of vegetation flammability (DELLA ROCCA et al., 2017).

Flammability was initially defined on the basis of three components: ignition potential, that is time required for the fuel to ignite after it has been exposed to a heat source; sustainability, referring to the ability to maintain combustion after ignition; and combustibility, that is the firing rate after ignition (ANDERSON, 1970).

The flammability characteristics are affected by several factors that can be classified into two groups: physical structures and components (size of branches, size and shape of leaves, retention of dead material); and physiological and cellular elements (volatile oils and resins, moisture content, mineral content, lignin and greases (WHITE; ZIPPERER, 2010).

FLORESTA, Curitiba, PR, v. 51, n. 1, p. 192-200, jan/mar 2021.

Batista, A. C. et.al.

ISSN eletrônico 1982-4688

DOI: $10.5380 /$ rf.v51 i1. 67938 
Fire risk assessments, which can help prevent and manage forest fires in wildland-urban interface areas, generally include estimates of dead and live fuel load, spatial arrangement of vegetation, and flammability of individual species (GHERMANDI et al., 2016).

To develop and improve a new approach to measure and compare flammability and combustion properties of forest species is fundamental (MADRIGAL et al., 2009). Flammability is experimentally evaluated by burning fuels in the laboratory, either in the form of discrete elements (e.g. a leaf, a branch) for which the concept was coined, or as a fuel bed or a heterogeneous set of individual units (FERNANDES; CRUZ, 2012).

Assuming the hypothesis that native species have a flammability different from exotic ones, because they are more adapted to local characteristics, the native species are more suitable for use in safety curtains. For this reason, the objective of this work was to evaluate the flammability of native and exotic ornamental species with potential for being used in the fire management in the wildland-urban interface areas of Paraná.

\section{MATERIAL AND METHODS}

All laboratory experiments for the development of this research were carried out in the Forest Fire Laboratory of the Forest Sciences Department, located in Federal University of Paraná Campus III, in Curitiba. The tests were conducted in the summer, with atmospheric conditions of $22.3^{\circ} \mathrm{C}$ and $57 \%$ relative humidity. The whole methodology was based on the research of Batista et al. (2013).

Based on the morphological characteristics associated with the flammability of the vegetation, thirteen species commonly found in the urban and forest remnants of wildland-urban interface Curitiba were selected, eight of which were native to the Mixed Ombrophilous Forest and the Grassy-woody steppe and five exotic species from Brazil. The native species evaluated were: Asclepias curassavica L. (Apocynaceae), Aspilia montevidensis (Spreng.) Kuntze (Asteraceae), Eryngium elegans Cham. \& Schlitdl. (Apiaceae), Hyptis meridionalis Harley \& J.F.B. Pastore (Lamiaceae), Leandra australis (Cham.) Cogn. (Melastomataceae), Verbena rigida Spreng. (Verbenaceae), all herbaceous; and Bougainvillea glabra Choisy (Nyctaginaceae) and Lantana camara L. (Verbenaceae), shrubs. From these, only B. glabra occurs exclusively in the Mixed Ombrophilous Forest, while A. montevidensis, E. elegans and H. Meridionalis occurs exclusively in the Grassy-woody steppe, and the others occur in both environments.

The exotic species evaluated, all shrubs, were: Camellia japonica L. (Theaceae), Euonymus japonicus Thunb. (Celastraceae), Jasminum mesnyi Hance (Oleaceae), Rhododendron simsii Planch. (Ericaceae), Viburnum odoratissimum Ker Gawl. (Adoxaceae).

For the laboratory experiments, leaves and thin branches $(<0.7 \mathrm{~cm}$ in diameter $)$ were collected from the crowns of the previously selected species, all at maturity stage. The collection of material was carried out on days without precipitation, with the absence of rain in the previous $24 \mathrm{~h}$. Soon after the collection, this material was placed in hermetically sealed plastic bags, weighed and identified in detail with each sample receiving an identification tag. This material was then sent to the forest fire laboratory to have the flammability tests carried out (KOVALSYKI et al., 2016).

Initially, the species were evaluated according to the main morphological characteristics of the leaves related to the flammability, such as leaf texture, presence of exudates, hairiness and enervation. The information for this evaluation was obtained through direct observations of the collected material, comparison with physical and virtual herbarium material or queries to secondary sources.

The flammability tests were performed according to the methodology proposed by Petriccione et al. (2006), Ganteaume et al. (2011) and Ganteaume et al. (2013).

Samples were used within 2 hours after collection to avoid possible changes (or contamination). Experimental burns were performed in an epi radiator, with a controlled temperature of $350^{\circ} \mathrm{C}$. In order to guarantee the homogeneity of the meteorological conditions during the experiment, the equipment was installed in a chapel, which is free of air drafts. It was also necessary to have a pilot flame, located in the center of the disc and $4 \mathrm{~cm}$ above the disc.

Flammability measurements were performed using an epi radiator (Figure 1). This instrument consists of a metal coil connected to a $100 \mathrm{~mm}$ pure silica disc in diameter; the power is $500 \mathrm{~W}$ and it produces a constant irradiation of $7.5 \mathrm{~W} / \mathrm{cm}^{2}$ and $3 \mathrm{~W} / \mathrm{cm}^{2}$ when $30 \mathrm{~mm}$ away from the disc. The surface temperature is $420{ }^{\circ} \mathrm{C}$.

FLORESTA, Curitiba, PR, v. 51, n. 1, p. 192-200, jan/mar 2021.

Batista, A. C. et.al.

ISSN eletrônico 1982-4688 

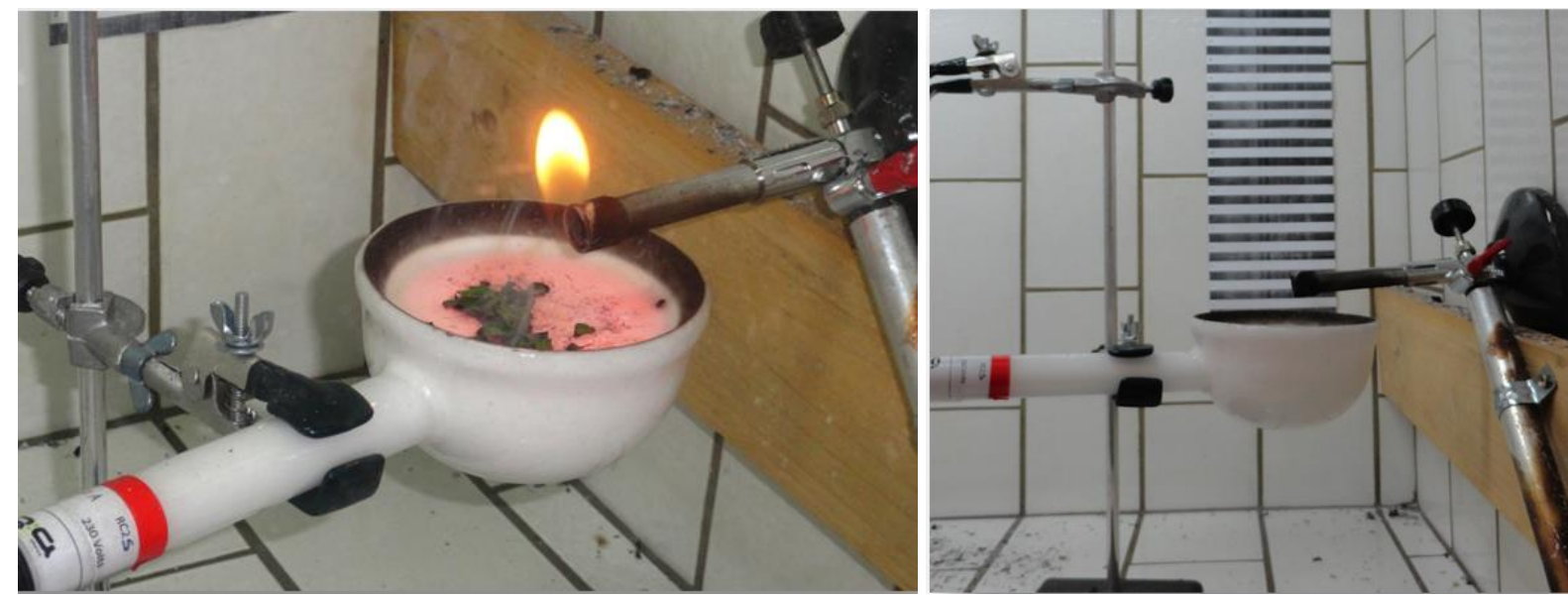

Figure 1. Demonstration of the experiment carried out with the epi radiator, in the chapel. On the left, detail of the pilot flame and on the right its location in the center of the disc.

Figura 1. Demonstração do experimento realizado com o epiradiador, na capela. À esquerda, detalhe da chama piloto e à direita sua localização no centro do disco.

For each evaluated species, 50 firing repetitions were performed. At each burn, $1 \pm 0.1 \mathrm{~g}$ of the harvested plant material of each species was used as fuel. All steps were performed without direct contact with the material to avoid influence on the natural properties of the samples.

The following combustion characteristics were analyzed, as proposed by Valette (1990) and Petriccione et al. (2006): Time to ignition (TI), regarding to time the material takes to start the combustion; Ignition frequency (FI), that is number of repetitions in which the ignition occurred, considering a maximum TI of $60 \mathrm{~s}$, the burnings that exceeded this time were classified as "negative burns"; Duration of combustion (DC), regarding to time the flame stays lit; Combustion index (CI), that is the combustion intensity of each burn, being determined by means of the flame heights and classified as proposed by Gautamme et al. (2013), with Very low $(<1 \mathrm{~cm})$, Low $(1-3$ $\mathrm{cm})$, Medium (4 $-7 \mathrm{~cm})$, High $(8-12 \mathrm{~cm})$ and Very high (> $12 \mathrm{~cm})$; and Flammability value (VI), assigned according to IF and TI (Table 1).

Table 1. Flammability value (VI) as a function of the ignition frequency (IF) and average time to ignition (TI) variables.

Tabela 1. Valor de inflamabilidade (VI) em função das variáveis frequência de ignição (IF) e tempo médio para ignição (TI).

\begin{tabular}{ccccccc}
\hline \multirow{2}{*}{ TI (s) } & \multicolumn{5}{c}{ Absolute Ignition Frequency (IF) } \\
\cline { 2 - 7 } & $\mathbf{2 5}$ & $\mathbf{2 5 - 3 8}$ & $\mathbf{3 9 - 4 1}$ & $\mathbf{4 2 - 4 4}$ & $\mathbf{4 5 - 4 7}$ & $\mathbf{4 8 - 5 0}$ \\
\hline$>32,5$ & 0 & 0 & 0 & 1 & 1 & 2 \\
$27,6-32,5$ & 0 & 0 & 1 & 1 & 2 & 2 \\
$22,6-275$ & 0 & 0 & 1 & 2 & 2 & 2 \\
$17,6-22,5$ & 1 & 1 & 2 & 2 & 3 & 3 \\
$12,6-17,5$ & 1 & 1 & 2 & 3 & 3 & 4 \\
$<12,6$ & 1 & 2 & 3 & 3 & 4 & 5 \\
\hline
\end{tabular}

Note: Valette's classification (Valette, 1990): slightly flammable (VI=0), weakly flammable (VI=1), moderately flammable (VI=2), flammable $(\mathrm{VI}=3)$, highly flammable $(\mathrm{VI}=4)$, and extremely flammable $(\mathrm{VI}=5)$.

At the end of the test phase, the analysis of variance (ANOVA) for each species was applied. For the burnings classified as negative, TI was considered $60 \mathrm{~s}$, DC zero $\mathrm{s}$ and CI zero $\mathrm{cm}$.

In order to verify the contribution of the two groups of variables in the flammability of the analyzed species, a cluster analysis was performed from a data matrix composed of the morphological characteristics and variables of the combustion. 


\section{RESULTS}

Table 2 shows the results of the evaluation of the leaves main morphological characteristics associated with flammability.

Table 2. Leaf characteristics associated with the studied species flammability.

Tabela 2. Características das folhas associadas à inflamabilidade das espécies estudadas.

\begin{tabular}{|c|c|c|c|c|c|c|}
\hline Species & Family & T. & Ex. & P. & E. & Positive Factors \\
\hline Asclepias curassavica & Apocynaceae & +++ & + & & ++ & ++++++ \\
\hline Aspilia montevidensis & Asteraceae & ++ & & + & ++ & +++++ \\
\hline Bougainvillea glabra & Nyctaginaceae & +++ & & & ++ & +++++ \\
\hline Eryngium elegans & Apiaceae & ++ & & & ++ & ++++ \\
\hline Hyptis meridionalis & Lamiaceae & +++ & & & + & ++++ \\
\hline Lantana camara & Verbenaceae & +++ & & + & + & +++++ \\
\hline Leandra australis & Melastomataceae & +++ & & + & + & +++++ \\
\hline Verbena rigida & Verbenaceae & +++ & & + & ++ & +++++ \\
\hline Camellia japonica & Theaceae & ++ & ++++ & & ++ & ++++++++ \\
\hline Euonymus japonicus & Celastraceae & ++ & + & & ++ & +++++ \\
\hline Jasminum mesnyi & Oleaceae & ++ & ++++ & & ++ & +++++++ \\
\hline Rhododendron simsii & Ericaceae & +++ & +++ & + & ++ & +++++++++ \\
\hline Viburnum odoratissimum & Adoxaceae & ++ & ++++ & & ++ & ++++++++ \\
\hline
\end{tabular}

Caption: T. = leaf texture: membranous $(+++)$, coriaceous $(++)$, fleshy $(+)$; Ex. $=$ Presence of exudates: essential oils $(++++)$, alcohol $(+++)$, phenols $(++)$ latex $(+) ;$ P. = hairiness: presence of hairiness $(+) ; \mathrm{E}=$ enervation: high enervation $(+)$, low enervation $(++)$. Positive Factors $=$ higher number of "+" favors flammability

It is observed in Table 2 that Camelia japonica, Jasminum mesnyi, Rhododendron simsii and Viburnum odoratissimum were the species that presented the greatest number of favorable to flammability leaf characteristics. The next phase of this study was to evaluate the variables TI, FI, DC and CI of the combustion, obtained during the burns in the epi radiator to determine the flammability. These were analyzed separately, which allowed to verify the behavioral difference among the studied species.

It is observed in the native species, in general, the TI was over $60 \mathrm{~s}$ in most of the repetitions, which corresponds to the negative ignitions. It is worth noting that the Verbena rigida was the only species that presented variation in the TI, presenting for the majority of repetitions values inferior to $60 \mathrm{~s}$, corresponding to the positive ignitions. However, the variables DC and CI were only possible to be analyzed in detail in the native species Verbena rigida because the other species exceeded 60 seconds of TI in the great majority of repetitions, indicating negative ignition. In this way, without ignition there was no combustion. For all exotic species, these variables were also calculated.

Table 3 shows the mean values of the epi radiator combustion variables of the studied species, with the respective flammability value (VI), obtained as a function of FI and TI.

Table 3. Parameters of flammability of ornamental species used in the wildland-urban interface of Paraná.

Tabela 3. Parâmetros de inflamabilidade das espécies ornamentais utilizadas em áreas da interface urbano-rural do Paraná.

FLORESTA, Curitiba, PR, v. 51, n. 1, p. 192-200, jan/mar 2021.

Batista, A. C. et.al.

ISSN eletrônico 1982-4688 


\begin{tabular}{|c|c|c|c|c|c|c|c|}
\hline Origin & Species & $\begin{array}{c}\text { FI } \\
(\%)\end{array}$ & $\begin{array}{l}\text { TI } \\
\text { (s) }\end{array}$ & $\begin{array}{l}\mathrm{DC} \\
(\mathrm{s})\end{array}$ & $\begin{array}{c}\mathrm{AC} \\
(\mathrm{cm})\end{array}$ & IC & VI \\
\hline \multirow{8}{*}{$\begin{array}{c}\text { Nati } \\
\text { ve }\end{array}$} & Bougainvillea glabra & $10,0 \mathrm{c}$ & 59,74 a & 7,00 & 16,8 & 5 & 1 - weakly flammable \\
\hline & Asclepias curassavica & $0,0 \mathrm{c}$ & $>61 \mathrm{a}$ & - & - & 1 & 1 - weakly flammable \\
\hline & Aspilia montevidensis & $2,0 \mathrm{c}$ & $>60 a$ & 13,00 & 9,0 & 4 & 1 - weakly flammable \\
\hline & Eryngium elegans & $4,0 \mathrm{c}$ & $>60 \mathrm{a}$ & 11,00 & 5,0 & 3 & 1 - weakly flammable \\
\hline & Hyptis meridionalis & $10,0 \mathrm{c}$ & 59,20 a & 9,20 & 15,2 & 5 & 1 - weakly flammable \\
\hline & Lantana camara & $8,0 \mathrm{c}$ & 59,84 a & 10,50 & 14,7 & 5 & 1 - weakly flammable \\
\hline & Leandra australis & $2,0 \mathrm{c}$ & $>60 \mathrm{a}$ & 14,00 & 13,0 & 5 & 1 - weakly flammable \\
\hline & Verbena rigida & $76,0 \mathrm{~b}$ & $55,88 \mathrm{~b}$ & 7,60 & 11,1 & 4 & 2 - moderately flammable \\
\hline \multirow{5}{*}{$\begin{array}{l}\text { Exo } \\
\text { tic }\end{array}$} & Camellia japonica & $100 \mathrm{a}$ & $18,70 \mathrm{e}$ & 14,72 & 12,1 & 5 & 4 - highly flammable \\
\hline & Euonymus japonicus & $66,0 \mathrm{~b}$ & $49,18 \mathrm{c}$ & 28,68 & 17,4 & 5 & 0 - slightly flammable \\
\hline & Jasminum mesnyi & $100 \mathrm{a}$ & $10,92 \mathrm{f}$ & 18,54 & 13,9 & 5 & 3 - flammable \\
\hline & Rhododendron simsii & 98,0 a & $18,80 \mathrm{e}$ & 26,94 & 8,6 & 4 & 2 - moderately flammable \\
\hline & Viburnum odoratissimum & 88,0 a & $23,29 \mathrm{~d}$ & 5,38 & 11,9 & 4 & 3 - flammable \\
\hline
\end{tabular}

Note: For the variables FI and TI, the averages followed by the same letter in the column do not differ from each other to $5 \%$ of significance by the SNK test.

The results showed that the FI variable was lower in all native species, differing statistically from the exotic ones. There was a statistical difference for the variable (TI), with higher values found in the native species. The low frequency of ignition in the native species made it impossible to perform the statistical analysis of the DC and AC variables.

The Figure 2 presents the dendrogram resulting from the Cluster analysis, using the mean values of the combustion parameters and the total values obtained for the morphological characteristics of the leaves of the tested species.

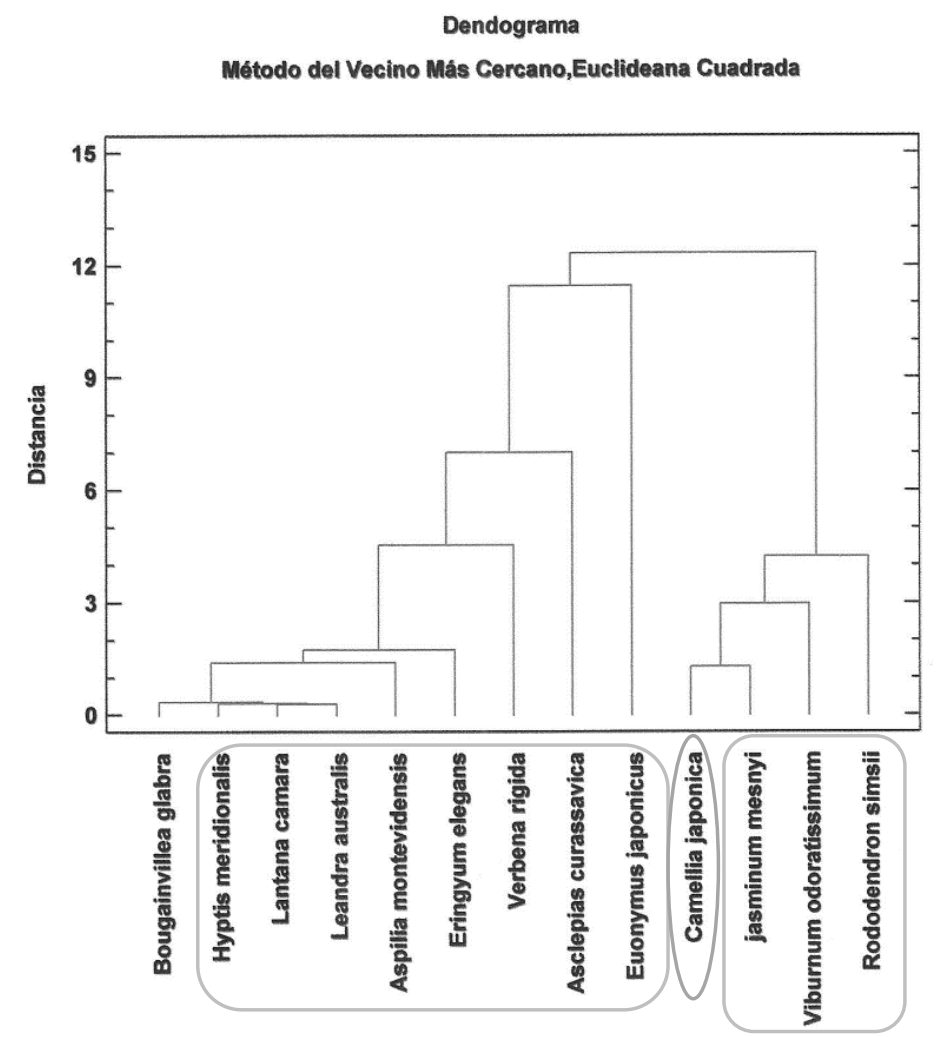

FLORESTA, Curitiba, PR, v. 51, n. 1, p. 192-200, jan/mar 2021.

Batista, A. C. et.al.

ISSN eletrônico 1982-4688 
Figure 2. Dendrogram indicating the species distinction in three groups according to the flammability.

Figura 2. Dendrograma indicando a distinção de espécies em três grupos de acordo com a inflamabilidade.

The results of the cluster analysis, according to the morphological characteristics of the leaves and the combustion parameters confirm the results obtained with the individual analysis. This analysis considered two groups of variables, the leaf morphology and flammability index. The grouping that brings together the species Asclepias curassavica, Aspilia montevidensis, Bougainvillea glabra, Eryngium elegans, Hyptis meridionalis, Lantana camara, Leandra australis and Verbena rigida is associated with low flammability values (1 and 2) and positive leaf morphological values ranging from 4 to 6 . The grouping represented by the species Camellia japonica, Jasminum mesnyi, Rhododendron simsii and Viburnum odoratissimum is associated with flammability values ranging from 2 to 4 and positive morphological values of leaves from 7 to 9 . The third group represented by the species Euonymus japonicus is associated with the null flammability value and 5 positive morphological values of the leaves.

\section{DISCUSSION}

The morphological analysis of the leaves was made as a way to complement the results obtained in the flammability test. Several authors have used these morphological characteristics in the definition of the degree of flammability of the species. Calitz et al. (2015) used these same morphological characteristics to assess the flammability of species from five biomes in South Africa and found that especially the succulents have low flammability, besides stating that that non-flammable species have large leaves sparsely arranged on coarse twigs. Although these authors have not obtained robust relationships between the analyzed morphological characteristics and the flammability of the species, the responses based on morphological characteristics are mostly consistent with other related studies like Batista and Biondi (2009), White and Zipperer (2010) and Pausas et al. (2015).

Although the less flammable species mostly presented high leaf enervation index, the less flammable species in the present study also had a high leaf enervation, not allowing to establish a relationship between these characteristics. It should be noted that Batista and Biondi (2009) already observed that low flammability plants are generally drought-tolerant, with high leaf enervation, indicating abundant water transport or high moisture content, while plants with high flammability present oily or waxy resinous leaves and chemical composition containing lignin and water. This statement was also made by White and Zipperer (2010) which added to these factors the mineral content and volatile content.

It was proven that the most flammable species were those with the presence of exudates, categorized as essential oils. This results befit Pausas et al. (2015), in his research the author also stated that essential oils are factors that influence the flammability of plant species.

For the exotic species, it is possible to notice great variation in the TI and predominance of the values below $60 \mathrm{~s}$, which corresponds to the positive ignitions. Euonymus japonicus was the species that took the longest to start the ignition, $48.8 \mathrm{~s}$ on average, even so in $66 \%$ of the repetitions there were positive ignitions. Jasminum mesnyi, on the other hand, was the species that ignited faster in all replicates, with an average of $10.9 \mathrm{~s}$, and $100 \%$ positive ignition, followed by Rhododendron simsii (17.9 s) and Camellia japonica (18.7 s).

There was great variation in the DC of all species in the repetitions performed. On average Verbena rigida combustion lasted 7.6 seconds, with the shortest recorded time being 4 seconds and the highest being 10 seconds. Euonymus japonicus was the species with the highest DC in its repetitions $(28.7 \mathrm{~s})$, ranging from 10 to $63 \mathrm{~s}$, followed by Rhododendron simsii (26.9 s), with a variation from 9 to 46 . The lowest DC was verified for Viburnum odoratissimum (5.4 s).

As for the CI variable, a great variation between the repetitions of each species is also observed. For Verbena rigida the CI average was $11.1 \mathrm{~cm}$, varying from 3.0 to $15.0 \mathrm{~cm}$. However, the height of the flame is associated with the expansion of the heated gases that are emitted during combustion in the epi radiator, and additional studies are needed to identify the volatile organic compounds that are present in the tested species.

Among the exotic species, Euonymus japonicus obtained the highest CI $(17.4 \mathrm{~cm})$, with a variation of 7 to $26 \mathrm{~cm}$, followed by Jasminum mesnyi $(13.9 \mathrm{~cm})$, which ranged from 8 to $23 \mathrm{~cm}$. Rhododendron simsii was the species with the lowest IC, $8.6 \mathrm{~cm}$, with a variation of 3 to $15 \mathrm{~cm}$.

Most native species showed negative ignitions. Verbena rigida was the only one to show positive ignitions. The favorable results of FI, TI, DC and AC found for the native species in WUI areas may be associated with the adaptability of the species to the site. Calitz et al. (2015), when analyzing a significant number of species from South Africa, pointed out several variations among them, even in similar conditions, thus concluding that different species from the same biome can develop adaptation mechanisms to become less flammable in their natural habitat. This may be a favorable indication for the usage of local native species.

FLORESTA, Curitiba, PR, v. 51, n. 1, p. 192-200, jan/mar 2021.

Batista, A. C. et.al.

ISSN eletrônico 1982-4688

DOI: $10.5380 /$ rf.v51 i1. 67938 
The only native species that had already been analyzed before was Bougainvillea glabra, which is the only one that occurs exclusively in the Mixed Ombrophilous Forest. In the study mentioned before, the researchers compared several woody species, and B.glabra presented one of the best results regarding the flammability variables (KOVALSYKI et al., 2016).

These results obtained with the combustion variables show similarity with the results obtained in the analysis of the morphological characteristics, as to know, the majority of the native species showed lower flammability levels than those of the exotic species.

The Cluster analysis aimed to combine the variables of the two tests applied. With the results, it was possible to distinguish three levels of flammability:

- Group 1 (weakly flammable) - composed by the species Asclepias curassavica, Bougainvillea glabra, Leandra australis, Lantana camara, Eryngium elegans, Hyptis meridionalis, Aspilia montevidensis and Verbena rigida;

- Group 2 (flammable) - composed by Camellia japonica, Jasminum mesnyi, Rhododendron simsii and Viburnum odoratissimum;

- Group 3 (slightly flammable) - composed by the species Euonymus japonicus.

The results of the cluster analysis, which partly identified three groups of flammability through the joint evaluation of the combustion parameters and the morphological characteristics of the leaves, reinforce the results obtained previously.

The results presented in this research are not decisive or complete, they determine some trends that can be explored with other tests and consequently with other characteristics of the plants. It must be considered that the morphological variables used in this research were analyzed linearly, as if they all had the same weight. Therefore, maybe due to the peculiarities of a plant, only one specific positive factor might have more influence on the flammability than five positive factors.

These results are very important for the management of urban and road trees in the areas of wildlandurban interface because the use of native species, besides reducing the risk of fires due to their lower flammability, promotes greater interest of its users to the floristic composition, closer connection with each site, better economic results due to the favorable chances of seedling survival and better conditions to reconstitute the flora and fauna (BIONDI, 2013).

\section{CONCLUSION}

- From the results obtained, it can be inferred that among the analyzed species, the native species presented low levels of flammability (weakly flammable), when compared with the exotic ones (flammable), with the exception of the Euonymus japonicus species that presented null flammability (slightly flammable).

- This means that the use of these species, Camellia japonica, Jasminum mesnyi, Rhododendron simsii and Viburnum odoratissimum (with the exception of Euonymus japonicas), should be avoided in the landscaping of areas at risk of forest fires or landscaping near the houses in the wildland-urban interface.

- In this way, it is concluded that the native species analyzed by this research are preferentially indicated to compose barriers against forest fires in wildland-urban interface areas in Paraná state.

\section{REFERENCES}

ANDERSON, H. E. Forest fuel ignitibility. Fire Technology, New York, v. 6, p.312-319, 1970.

BARTOLI, P.; SIMEONI, A.; BITEAU, H.; TORERO, J.L.; SANTONI, P. A. Determination of the main parameters influencing forest fuel combustion dynamics P. Fire Safety Journal, Amsterdam, v. 46, p. 27-33, 2011.

BATISTA, A. C., BIONDI, D. Avaliação da inflamabilidade de Ligustrum lucidum Aiton (Oleaceae) para uso potencial em cortinas de segurança na região sul do Brasil. Revista Brasileira de Ciências Agrárias, Recife, v.4, n.4, p.435-439, 2009.

BATISTA, A.C.; BIONDI, D.; TETTO, A. F.; ASSUNCAO, R.; TRES, A.; TRAVENISK, R. C.; KOVALSKY, B. Evaluation of the Flammability of Trees and Shrubs Used in the Implementation of Green Barriers in Southern Brazil. General Technical Report PSW-GTR, Washington, v. 245, p. 256-264, 2013.

BIONDI, D. Paisagismo Rodoviário: indicação de espécies. O Autor, 2013. 54p.

CALITZ, W.; POTTS, A. J.; COWLING, R. M. Investigating species-level flammability across five biomes in the Eastern Cape, South Africa. South African Journal of Botany, Amsterdam, v. 101, p.32-39, 2015.

FLORESTA, Curitiba, PR, v. 51, n. 1, p. 192-200, jan/mar 2021.

Batista, A. C. et.al.

ISSN eletrônico 1982-4688

DOI: $10.5380 /$ rf.v51 i1. 67938 
CURT, T.; SCHAFFHAUSER, A.; BORGNIET, L.; DUMAS, C.; ESTÈVE, R.; GANTEAUME, A.; JAPPIOT, M.; MARTIN, W.; N'DIAYE, A.; POILVET, B. Litter flammability in oak woodlands and shrublands of southeastern France. Forest Ecology and Management, Amsterdam, v. 261, p. 2214-2222, 2011.

DELLA ROCCA, G.; MADRIGAL, J.; MARCHI, E.; MICHELOZZI, M.; MOYA, B.; DANTI, R. Relevance of terpenoids on flammability of Mediterranean species: an experimental approach at a low radiant heat flux. iForest, Naples, v. 10, p.766-775, 2017.

FERNANDES, P. M.; CRUZ, M.G. Plant flammability experiments offer limited insight into vegetation-fire dynamics interactions. New Phytologist, Oakley, v. 194, p.606-609, 2012.

GANTEAUME, A.; JAPPIOT, M.; LAMPIN, C.; GUIJARRO, M.; HERNANDO, C. Flammability of some ornamental species in wildland-urban interfaces in Southeastern France: laboratory assessment at particle level. Journal Environmental Management, Amsterdam, v. 52, p.467-480, 2013.

GANTEAUME, A.; JAPPIOT M.; LAMPIN, C.; THOMAS, C.; LAURENT, B. Effects of vegetation type and fire regime on flammability of undisturbed litter in Southeastern France. Forest Ecology and Management, Amsterdam, v. 261, p. 2223-2231, 2011.

GHERMANDI, L. A.; BELETZKY, N. A.; CURTH, M.I.T.; ODDI, F. J. From leaves to landscape: A multiscale approach to assess fire hazard in wildland-urban interface áreas. Journal of Environmental Management, Amsterdam, v.183, p. 925-937, 2016.

KOVALSYKI, B.; TAKASHINA, I. K.; TRES, A.; TETTO, A. F.; BATISTA, A. C. Inflamabilidade de espécies arbóreas para uso em cortinas de segurança na prevenção de incêndios florestais, Pesquisa Florestal Brasileira, Colombo, v. 36, n. 88, p.387-392, 2016.

MADRIGAL, J.; HERNANDO, C.; GUIJARRO, M.; DIEZ, C.; MARINO, E.; CASTRO, A.J. Evaluation of forest fuel flammability and combustion properties with a adapted mass loss calorimeter device. Journal of Fire Sciences, Thousand Oaks, v. 27, p.321-342, 2009.

MADRIGAL, J.; HERNANDO, C.; GUIJARRO, M. A new bench-scale methodology for evaluating the flammability of live forest fuels. Journal of Fire Sciences, Thousand Oaks, v. 31, n. 2, p. 131-142, 2013.

MOLINA, J. R.; MARTÍN, T.; RODRÍGUEZ Y SILVA, F.; MIGUEL ÁNGEL HERRERA, M. A. The ignition index based on flammability of vegetation improves planning in the wildland-urban interface: A case study in Southern Spain. Landscape and Urban Planning, Amsterdam, v.158, p. 129-138, 2017.

MORENO, J. M. Impactos en el riesgo potencial de incêndios debidos al cambio climático. In: BIROT, Y. Convivir con los incendios forestales: lo que nos revela la ciencia. European Forest Institute, 2009. p. 77-80.

PAUSAS, J. G.; ALESSIO, G. A.; · MOREIRA, B.; SEGARRA-MORAGUES. J. G. Secondary compounds enhance flammability in a Mediterranean plant. Oecologia, New York, v.180, p.103-110, 2016.

PETRICCIONE, M.; MORO, C.; RUTIGLIANO, F. A. Preliminary studies on litter flammability in Mediterranean region. Forest Ecology and Management, Amsterdam,v. 234, p. 128-128, 2006.

SOUZA, M. A; VALE, A. T. Levantamento de plantas de baixa inflamabilidade em áreas queimadas de cerrado no Distrito Federal e análise das suas propriedades físicas. Ciência Florestal, Santa Maria, v. 29, n. 1, p. 181-192, 2019.

VALETTE, J. C. Inflammabilités des espèces forestières méditerranéennes. Rev. Forest. Fr., v. 42, p.76-92, 1990.

WHITE, R. H.; ZIPPERER, W. C. Testing and classification of individual plants for fire behaviour: plant selection for the wildland-urban interface. International Journal of Wildland Fire, Clayton South, v. 19, p. 213-227, 2010 .

ZHAN, Z.; ZHANG, Z.; ZHOU, D. Flammability characterization of grassland species of Songhua Jiang-Nen Jian Plain (China) using thermal analysis. Fire safety Journal, Amsterdam, v. 46, n.5, p. 283-288, 2011. 